\title{
ANALISIS KEPUASAN KUALITAS LAYANAN SISTEM INFORMASI AKADEMIK MENGGUNAKAN METODE TAM III
}

\author{
Anastasia Mude ${ }^{1}$, Ferdinandus Lidang Witi ${ }^{2}$ \\ ${ }^{1,2}$ Program Studi Sistem Informasi, Fakultas Teknologi Informasi, Universitas Flores \\ Jl. Sam Ratulangi, Kelurahan Paupire, Kecamatan Ende Tengah, \\ Kabupaten Ende - Flores - NTT - Indonesia 86318 \\ Email : anastasiamude@uniflor.ac.id ${ }^{1}$, ferdylidang@uniflor.ac.id ${ }^{2}{ }^{2}$
}

\begin{abstract}
This research aimed to comprehend the effect of variables external consisting of experience, subjective norm, perceptions, job relevance, output quality and result demonstrability, computer self efficacy, perceptions of external control, computer anxiety, computer playfulness, perceived enjoyment, and objective usability for perceived usefulness, perceived easy of use, service quality, behavioral intention, use behavior and user satisfaction of academic information system. The population of this students of AMIK Parna Raya Manado in academic year of 2013 and 2014. By using Slovin method, it was obtained the rate of the sample amount of 120 students. Data collection techniques using questionnaires and the model used Technology Acceptance Model (TAM III). It had been used Structural Equation Model (SEM) for examining the relation between those variables. The result of showed that the use TAM III method of significantly affected of the service quality satisfaction of academic information system.
\end{abstract}

Keywords : Technology Acceptance Model, Structural Equation Model

\begin{abstract}
ABSTRAK
Penelitian ini bertujuan untuk mengetahui pengaruh variabel-variabel eksternal yang terdiri dari pengalaman, norma subyektif, persepsi, relevansi pekerjaan, kualitas output dan hasil demonstrasi, kemampuan diri dalam komputer, persepsi kontrol eksternal, kecemasan penggunaan komputer, penggunaan sepenuhnya pada komputer, kenikmatan yang dirasakan, dan kegunaan obyektif terhadap persepsi kemanfaatan, persepsi kemudahan, kualitas layanan, perilaku untuk tetap menggunakan, perilaku nyata penggunaan sistem, dan kepuasan penggunaan sistem informasi akademik. Populasi dalam penelitian ini adalah mahasiswa AMIK Parna Raya Manado angkatan tahun 2013 dan 2014. Sampel dalam penelitian ini sebanyak 120 orang menggunakan rumus Slovin. Teknik pengumpulan data menggunakan kuesioner dan model yang digunakan adalah Technology Acceptance Model III (TAM III). Untuk pengujian hubungan antara beberapa variabel tersebut digunakan software SEM PLS. Hasil penelitian menunjukan bahwa penggunaan metode TAM III berpengaruh secara signifikan terhadap kepuasan kualitas layanan sistem informasi akademik.
\end{abstract}

Kata kunci : Technology Acceptance Model, Structural Equation Model 


\section{Pendahuluan}

Sistem Informasi Akademik (SIAKAD) merupakan wadah bagi civitas akademika, terutama mahasiswa untuk mengakses berbagai data akademik yang dapat dilakukan dari mana dan kapan pun. Mahasiswa dapat memanfaatkan SIAKAD untuk melakukan aktivitas pembelajaran pada semester yang akan berlangsung sesuai dengan jumlah dan ketentuan yang berlaku. Adanya SIAKAD diharapkan dapat menyediakan informasi yang akurat, cepat dan tepat sehingga prosesnya dapat mempersingkat waktu dengan tidak mengurangi kualitas dari informasi serta lebih efisien dalam menyajikan informasi bagi semua pihak.

Sistem informasi akademik yang dijalankan, digunakan oleh mahasiswa sebagai penunjang keberhasilan dalam menempuh pendidikan di AMIK Parna Raya Manado, namun dalam prosesnya masih menghadapi kendala administrasi akademik dan kemahasiswaan seperti sulitnya mengakses situs SIAKAD pada saat pengisian kartu rencana studi (KRS), pemantauan kartu hasil studi (KHS), jumlah kelas yang dibuka tidak sesuai dengan banyaknya mahasiswa yang mengambil suatu mata kuliah tertentu, serta jadwal kuliah dan ujian kadang tidak sesuai karena tidak diperbarui jika ada perubahan, sehingga dapat mempengaruhi kepuasan mahasiswa terhadap sistem informasi akademik yang digunakan.

Untuk mengatasi masalah tersebut maka peneliti menggunakan metode Technology Acceptance Model III yang telah dimodifikasi dengan menambahkan variabel kualitas layanan dan kepuasan pengguna. Dalam TAM digambarkan bahwa penerimaan penggunaan TI dipengaruhi oleh kemanfaatan (usefulness) dan kemudahan penggunaan (ease of use) [1]. Kemanfaatan dan kemudahan penggunaan mempunyai pengaruh ke minat perilaku. Pemakai teknologi akan mempunyai minat menggunakan teknologi jika merasa sistem teknologi bermanfaat dan mudah digunakan. Pemakai sistem informasi akan lebih banyak memanfaatkan sistem jika sistem informasi tersebut mudah digunakan. Sebaliknya jika sistem informasi tidak mudah digunakan (rumit) pemakai akan lebih sedikit dalam memanfaatkan sistem informasi tersebut[3].

\section{Model Penelitian}

Model penelitian yang akan dikembangkan dalam penelitian ini dapat dilihat pada Gambar 1. 


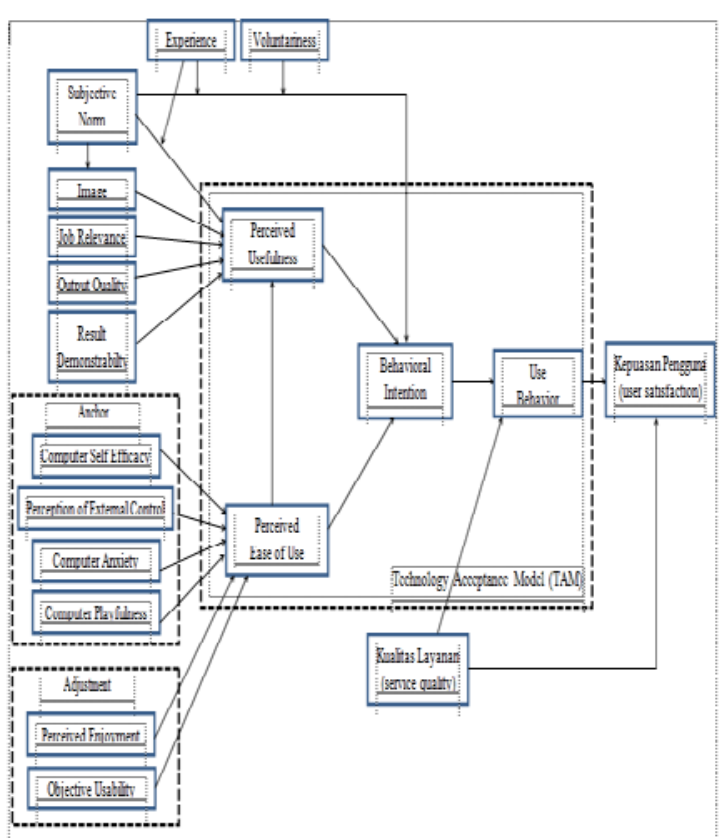

Gambar 1. Kerangka Penelitian

\section{Hipotesis}

Hipotesis dalam penelitian ini, adalah:

1. Persepsi kemanfaatan (Perceived Usefulness)

H1 : Variabel-variabel eksternal yang terdiri dari pengalaman (experience), norma subyektif (subjective norm), persepsi (image), relevansi pekerjaan (job relevance), kualitas output (output quality) dan hasil demonstrasi (result demonstrability) berpengaruh positif terhadap kemanfaatan sistem (perceived usefulness) dari sistem informasi akademik.

2. Persepsi Kemudahan (perceived ease of use)

H2: Variabel-variabel eksternal yang terdiri dari kemampuan diri dalam komputer (computer self effifacy), persepsi kontrol eksternal (perceptions of external control), kecemasan penggunaan komputer (computer anxiety), penggunaan sepenuhnya pada komputer (computer play fulness), kenikmatan yang dirasakan (perceived enjoyment), dan kegunaan obyektif (objective usability) berpengaruh positif terhadap kemudahan sistem (perceived ease of use) dari sistem informasi akademik.

3. Persepsi (image)

H3 : Norma subyektif (subjective norm) berpengaruh positif terhadap persepsi (image) dari sistem informasi akademik

4. Persepsi kemanfaatan (Perceived Usefulness)

H4 : Kemudahan sistem (perceived ease of use) berpengaruh positif terhadap kemanfaatan sistem (perceived usefulness) dari sistem informasi akademik.

5. Perilaku untuk tetap menggunakan (behavioral intention to use)

H5 : Variabel eksternal yang terdiri dari pengalaman (experience) dan sukarela (voluntariness) berpengaruh positif terhadap perilaku untuk tetap menggunakan (behavioral intention to use) dari sistem informasi akademik 
H6 : Kemanfaatan sistem (perceived usefulness) berpengaruh positif terhadap perilaku untuk tetap menggunakan (behavioral intention to use) dari sistem informasi akademik

H7 : Kemudahan sistem (perceived ease of use) berpengaruh positif terhadap perilaku untuk tetap menggunakan (behavioral intention to use) dari sistem informasi akademik

6. Perilaku nyata penggunaan sistem (behavioral actual system use)

H8: Perilaku untuk tetap menggunakan (behavioral intention to use) berpengaruh positif terhadap perilaku nyata penggunaan sistem (behavioral actual system use) dari sistem informasi akademik

7. Kualitas Layanan (service quality)

H9 : Kualitas layanan (service quality) berpengaruh positif terhadap perilaku nyata penggunaan sistem (behavioral actual system use) dari sistem informasi akademik.

H10: Kualitas layanan (service quality) berpengaruh positif terhadap kepuasan pengguna (user satisfaction) dari sistem informasi akademik.

8. Kepuasan pengguna (user satisfaction)
H11: Perilaku nyata penggunaan sistem (behavioral actual system use) berpengaruh positif terhadap kepuasan pengguna (user satisfaction) dari sistem informasi akademik.

\section{Metode Penelitian}

\subsection{Jenis Penelitian}

Objek penelitian pada sistem informasi akademik di AMIK Parna Raya Manado, dengan menganalisis kepuasan mahasiswa terhadap kualitas layanan sistem informasi akademik menggunakan model TAM III, dengan mengekplorasi masing-masing variabel, sehingga penelitian ini merupakan penelitian explanatory atau eksplanasi yang adalah jenis penelitian yang bertujuan untuk menganalisis hubungan-hubungan antara satu variabel dengan variabel lainnya atau bagaimana suatu variabel mempengaruhi variabel lainnya dengan pendekatan kuantitatif [5] dan pada akhir penelitian akan dianalisis untuk menguji hipotesis yang diajukan diawal penelitian ini.

\subsection{Metode Pengambilan Sampel}

Teknik pengambilan sampel dalam penelitian ini adalah Proportional Stratified Sampling, teknik ini digunakan bila populasi mempunyai anggota atau unsur yang tidak homogen dan berstrata secara proporsional . Dengan kata lain 
pengambilan sampel secara acak didalam populasi yang sudah dikelompokkan (distratakan).

Untuk masing-masing mahasiswa menurut jurusannya agar setiap mahasiswa mempunyai proporsi yang sama. Besar sampel dapat dicari dengan rumus :

$$
n i=\frac{N i}{\sum N} \times n_{0}
$$

Dalam hal ini :

$\mathrm{n}_{\mathrm{i}}=$ Banyaknya sampel mahasiswa dari tiap jurusan

$\mathrm{N}_{\mathrm{i}}=$ Banyaknya mahasiswa tiap jurusan

No = Banyaknya sampel

$\sum \mathrm{N}=$ Banyaknya populasi

Berdasarkan perhitungan diatas, maka jumlah sampel pada mahasiswa AMIK Parna Raya Manado yang akan digunakan, disajikan pada Tabel 1:

Tabel 1. Sampel Mahasiswa AMIK Parna Raya Manado

\begin{tabular}{clc}
\hline No & \multicolumn{1}{c}{ Jurusan } & Jumlah \\
\hline 1 & Manajemen Informatika & 48 \\
2 & Komputer Akuntansi & 33 \\
3 & Teknik Informatika & 39 \\
Jumlah & 120 \\
\hline
\end{tabular}

Sumber : Data diolah, 2015.

Skala yang dipakai pada penelitian untuk mengukur hasil kuesioner menggunakan skala likert yang berisi lima tingkat preferensi jawaban dengan pilihan jawaban, range 1 sampai 5 untuk jawaban sangat tidak setuju sampai jawaban sangat setuju.

\subsection{Metode Pengumpulan Data}

Data yang digunakan dalam penelitian ini adalah data primer yang dilakukan melalui penyebaran kuesioner. Pertanyaan pada kuesioner berisi butirbutir pengukur konstruk atau variabel dalam bentuk daftar pertanyaan dan pernyataan yang digunakan dalam model penelitian.

\subsection{Metode Analisis Data}

Teknik analisis yang digunakan dalam penelitian ini adalah model persamaan struktural atau SEM (Structural Equation Model) dengan menggunakan software PLS (Partial Least Square) dan bantuan program SPSS for windows 21.0. Program SPSS for windows 21.0 digunakan untuk melakukan uji validitas dan uji reliabilitas dari kuesioner tersebut. PLS adalah salah satu teknik SEM yang mampu menganalisis variabel laten, variabel indikator dan kesalahan pengukuran secara langsung [4].

Estimasi parameter yang didapat melalui PLS dapat dikelompokkan kedalam tiga kategori. Kategori pertama adalah weight estimate, digunakan untuk menciptakan skor variabel laten. Kategori kedua adalah merefleksikan path estimate yang menghubungkan variabel laten dan antara variabel dengan blok indikatornya. Kategori ketiga adalah berkaitan dengan rata-rata (means) dan location parameters 
untuk indikator dan variabel laten. Model evaluasi PLS dilakukan dengan menilai outer model dan inner model [4].

Pengujian hipotesis menggunakan Uji t untuk menunjukkan pengaruh variabel eksogen terhadap variabel endogen. Langkah-langkah pengujiannya adalah:

1) Menetapkan hipotesis operasional

Ho : tidak ada pengaruh dari variabel eksogen terhadap variabel endogen

Ha : ada pengaruh dari variabel eksogen terhadap variabel endogen

2) Menetapkan taraf signifikansi ( $\alpha)$ yaitu sebesar $5 \%$

3) Menetapkan kriteria penerimaan dan penolakan hipotesis:

Ho diterima jika $p \geq \alpha$ atau nilai $t_{\text {hitung }}$ $\leq \mathrm{t}_{\text {tabel }}$

Ha diterima jika $p<\alpha$ atau nilai $\mathrm{t}_{\text {hitung }}$ $>t_{\text {tabel }}$

4) Melakukan perhitungan dengan bantuan program PLS.

5) Menarik kesimpulan.

\section{Hasil dan Pembahasan}

\section{a. Hasil Uji Validitas}

Uji validitas digunakan untuk mengetahui seberapa cermat suatu test dapat melakukan fungsi ukurnya semakin tepat pula alat pengukur tersebut mengenai sasaran, dan sebaliknya semakin rendah suatu alat ukur maka semakin jauh pula alat pengukurnya tersebut mengenai sasarannya.

Pengujian validitas menggunakan teknik korelasi produk moment yaitu mengkorelasikan skor setiap item dengan skor variabel (hasil penjumlahan seluruh skor item pertanyaan) [3]. Item pertanyaan dinyatakan valid apabila memiliki nilai Corrected Item-Total Correlation lebih besar dari 0,3 [3].

Dari hasil uji validitas, menunjukkan semua item kuesioner pada 19 variabel dinyatakan valid, dikarenakan semua item kuesioner tersebut memiliki nilai Corrected Item-Total Correlation lebih besar dari 0,3.

\section{b. Hasil Uji Reliabilitas}

Uji reliabilitas dapat diartikan sebagai jawaban seseorang terhadap pertanyaan adalah konsisten atau stabil dari waktu ke waktu. Semakin tinggi koefisien reliabilitas semakin reliabel jawaban yang diperoleh dari responden [4].

Pengujian reliabilitas dalam penelitian ini dilakukan dengan menghitung besarnya nilai Cronbach's Alpha instrumen dari masing-masing variabel penelitian yang diuji. Apabila nilai Cronbach's Coefficient Alpha lebih besar dari 0,6, maka item pertanyaan pada kuesioner sebagai alat pengukur dinyatakan reliabel. 
Berdasarkan hasil analisis diperoleh nilai koefisien cronbach's alpha untuk 19 variabel tersebut memiliki nilai koefisien cronbach's alpha lebih besar dari 0,6; maka kesimpulannya bahwa instrumeninstrumen penelitian tersebut reliabel dan dapat digunakan sebagai alat pengumpulan data sesungguhnya.

\section{c. Analisis Data dan Pengujian Model Penelitian}

i. Evaluasi Model Pengukuran (Outer Model)

\section{a) Convergent Validity (Validitas Konvergen)}

Nilai Validitas konvergen adalah nilai Loading Factor (LF) pada variabel laten dengan indikator-indikatornya. Sesuai aturan umum, nilai LF indikator $>0,7$ dikatakan valid. Namun demikian pada riset tahap pengembangan model atau indikator baru, nilai LF antara 0,50 - 0,60 masih dapat diterima. Dalam penelitian ini akan digunakan batas nilai loading factor sebesar 0,50. Pada Tabel 2 akan disajikan nilai loading faktor dari semua indikator.

Tabel 2. Outer Loadings

\begin{tabular}{lc}
\hline \multicolumn{1}{c}{ Indikator } & Outer Loadings \\
\hline HD & 0,5880145 \\
KDDK & 0,8352333 \\
KL & 0,6545602 \\
KO & 0,6895363 \\
KOB & 0,8577870 \\
KP & 0,6419795 \\
KPK & 0,5871500 \\
KYD & 0,7089295 \\
\hline
\end{tabular}

\begin{tabular}{ll}
\hline NS & 0,8356537 \\
P & 0,7187160 \\
PK & 0,7573576 \\
PKE & 0,8346720 \\
PKM & 0,7559336 \\
PN & 0,3422094 \\
PNG & 0,8342480 \\
PSPK & 0,3654815 \\
PUTM & 0,7330543 \\
RP & 0,8301207 \\
SK & 0,2610220 \\
\hline
\end{tabular}

Berdasarkan nilai loading faktor pada tabel 2, yang memiliki nilai loading faktor $<0,50$ maka konstruk dari indikator tersebut belum memenuhi nilai convergent validity. Kemudian indikator yang memiliki nilai loading faktor $>$ 0,50 maka konstruk dari indikator tersebut telah memenuhi nilai convergent validity. Konstruk disebut juga variabel laten yaitu suatu ukuran yang abstrak, yang tidak dapat diamati langsung.

b) Discriminat Validity (Validitas Diskriminan)

Nilai Discriminant validity merupakan nilai cross loading faktor yang berguna untuk mengetahui apakah konstruk memiliki diskriminan yang memadai yaitu dengan cara membandingkan nilai loading pada konstruk yang dituju harus lebih besar dibandingkan dengan nilai loading dengan konstruk yang lain. Dari hasil pengujian discriminant validity terlihat bahwa nilai cross loading faktor setiap indikator 
berkorelasi lebih tinggi dengan konstruknya masing-masing dibandingkan dengan konstruk lainnya, sehingga hasil pengujian tersebut memiliki nilai discriminant validity yang baik.

c) Mengevaluasi Reliability dan Average Variance Extracted (AVE)

Nilai AVE/rata-rata varian yang diekstraksi digunakan untuk mengukur banyaknya varians yang dapat ditangkap oleh konstruknya dibandingkan dengan varians yang ditimbulkan oleh kesalahan pengukuran. Kriteria reliabilitas dapat dilihat dari nilai reliabilitas suatu konstruk dan nilai Average Variance Extracted (AVE) dari masing-masing konstruk. Konstruk dikatakan memiliki reliabilitas yang tinggi jika nilainya $>0,70$ dan AVE berada $>0,50$. Pada Tabel 3 akan disajikan nilai Composite Reliability dan AVE untuk seluruh variabel.

Tabel 3 Composite Reliability dan AVE

\begin{tabular}{lcr}
\hline Indikator & $\begin{array}{c}\text { Composite } \\
\text { Reliability }\end{array}$ & \multicolumn{1}{l}{ AVE } \\
\hline HD & 0,709950 & 0,578219 \\
KDDK & 0,874964 & 0,700923 \\
KL & 0,791198 & 0,534648 \\
KO & 0,748319 & 0,520269 \\
KOB & 0,851468 & 0,743292 \\
KP & 0,849836 & 0,517411 \\
KPK & 0,744340 & 0,529128 \\
KYD & 0,704073 & 0,577523 \\
NS & 0,874278 & 0,698745 \\
P & 0,705561 & 0,568872 \\
PK & 0,875296 & 0,591400 \\
PKE & 0,821406 & 0,697050 \\
\hline
\end{tabular}

\begin{tabular}{lll}
\hline PKM & 0,870240 & 0,573969 \\
PN & 0,704125 & 0,524045 \\
PNG & 0,881266 & 0,718692 \\
PSPK & 0,702268 & 0,553083 \\
PUTM & 0,823952 & 0,540736 \\
RP & 0,869983 & 0,691046 \\
SK & 0,705766 & 0,589137 \\
\hline
\end{tabular}

Berdasarkan Tabel 3 dapat disimpulkan bahwa semua konstruk memenuhi kriteria reliabel. Hal ini ditunjukkan dengan nilai composite reliability $>0,70$ dan $\mathrm{AVE}>$ 0,50 sebagaimana kriteria yang direkomendasikan.

\section{ii. Pengujian Model Struktural (Inner Model)}

Model struktural adalah model yang menghubungkan antar variabel laten. Model refleksif mencerminkan bahwa setiap indikator merupakan pengukuran kesalahan yang dikenakan terhadap variabel laten. Ukuran refleksif dikatakan valid jika memiliki nilai loading faktor $(\lambda)$ dengan variabel laten yang ingin diukur > 0.5, jika salah satu indikator memiliki nilai loading faktor $(\lambda)<0.5$ maka indikator tersebut harus dibuang karena akan mengindikasi bahwa indikator tidak cukup baik untuk mengukur variabel laten secara tepat, dan validitas konstruk tidak akan berubah jika satu indikator dibuang/dihilangkan. Untuk lebih jelasnya dapat dilihat pada Gambar 2 dan Gambar 3 berikut: 


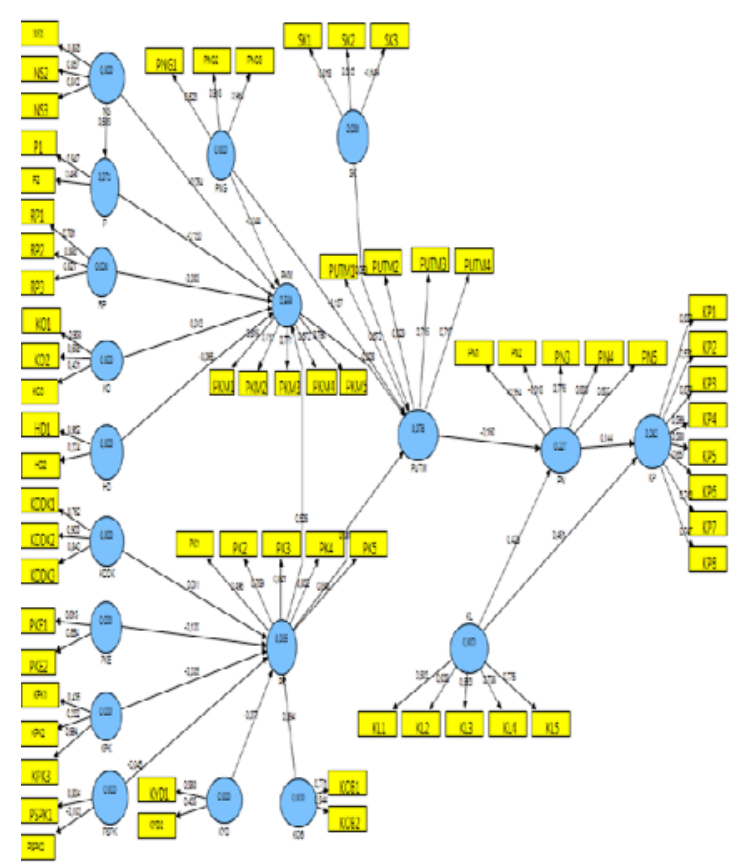

Gambar 2. Model Struktural Sebelum di Drop

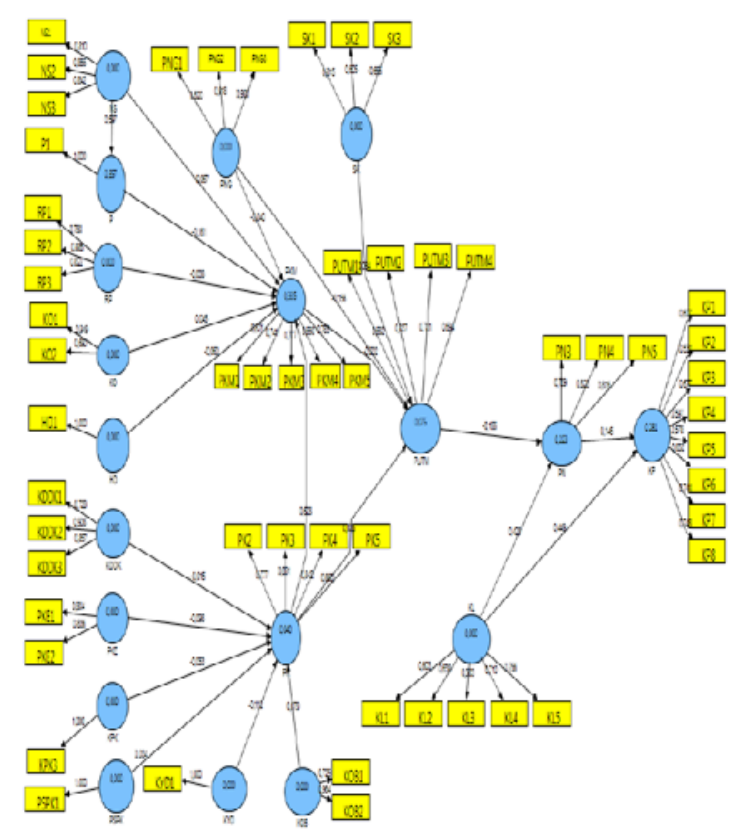

Gambar 3 Model Struktural Setelah di Drop

Berdasarkan gambar 3 terlihat bahwa tidak terdapat variabel yang memiliki indikator dengan nilai loading faktor $(\lambda)<$ 0.5 , sehingga model penelitian ini dapat dinyatakan memiliki model yang fit atau baik.

\section{d. Pengujian Hipotesis}

Signifikansi parameter yang diestimasi memberikan informasi yang sangat berguna mengenai hubungan antara variabel-variabel penelitian. Dasar yang digunakan dalam menguji hipotesis adalah nilai yang terdapat pada Path Coefficients (Mean, STDEV, T-Values) atau model struktural hasil penelitian adalah dengan mengevaluasi hubungan antar konstruk laten atau variabel seperti yang dihipotesiskan dalam penelitian. Penerimaan dan penolakan hipotesis dilakukan dengan membandingkan nilai $t_{\text {hitung dengan nilai }} t_{\text {tabel, dengan nilai }}$ $\mathrm{n}=120$ maka diperoleh nilai $\mathrm{t}_{\text {tabel }}$ sebesar 1,6578. Jika nilai $t_{\text {hitung }} \geq$ nilai $t_{\text {tabel }}$ maka dinyatakan ada pengaruh signifikan (hipotesis diterima) dan sebaliknya jika nilai $t_{\text {hitung }}<$ nilai $t_{\text {tabel }}$ maka dinyatakan tidak ada pengaruh (hipotesis ditolak). Hasil pengujian hipotesis dapat dilihat pada tabel 4 berikut. 
Tabel 4. Hubungan Kausalitas Model Hipotesis

\begin{tabular}{|c|c|c|c|c|c|c|c|}
\hline \multirow{2}{*}{$\begin{array}{c}\text { Hipotesis } \\
\text { H1 }\end{array}$} & & \multicolumn{3}{|c|}{ Patll Hubungan } & \multirow{2}{*}{$\begin{array}{r}\begin{array}{c}\text { Original } \\
\text { Sample }(0)\end{array} \\
0,039677\end{array}$} & \multirow{2}{*}{$\begin{array}{c}\begin{array}{c}\text { T Statistics } \\
(\text { O/STERR })\end{array} \\
2,350493\end{array}$} & \multirow{2}{*}{$\begin{array}{c}\text { Ket. } \\
\text { Terbukti }\end{array}$} \\
\hline & a & PNG & $\rightarrow$ & PKM & & & \\
\hline & $\mathrm{b}$ & NS & $\rightarrow$ & PKM & $-0,056841$ & 0,478923 & $\begin{array}{c}\text { Tidak } \\
\text { Terbuktit }\end{array}$ \\
\hline & c & $P$ & $\rightarrow$ & PKM & 0,160614 & 2,346280 & Terbukti \\
\hline & d & $\mathrm{RP}$ & $\rightarrow$ & PKM & 0,038320 & 1,893063 & Terbukti \\
\hline & $\mathrm{e}$ & KO & $\rightarrow$ & PKM & 0,045418 & 0,379874 & $\begin{array}{c}\text { Tidak } \\
\text { Terbukti }\end{array}$ \\
\hline & $\mathrm{f}$ & $\mathrm{HD}$ & $\rightarrow$ & PKM & 0,059890 & 1,829988 & Terbukti \\
\hline \multirow[t]{6}{*}{$\mathrm{H} 2$} & a & KDDK & $\rightarrow$ & PK & 0,014727 & 1,900387 & Terbukti \\
\hline & b & PKE & $\rightarrow$ & PK & 0,098320 & 0,657606 & Terbukti \\
\hline & c & $\mathrm{KPK}$ & $\rightarrow$ & PK & $-0,053494$ & 2,512604 & Terbukti \\
\hline & d & PSPK & $\rightarrow$ & PK & 0,033905 & 2,306795 & Terbukti \\
\hline & $\mathrm{e}$ & KYD & $\rightarrow$ & PK & 0,111672 & 0,938308 & Terbukti \\
\hline & $f$ & $\mathrm{KOB}$ & $\rightarrow$ & PK & 0,079255 & 1,927708 & Terbukti \\
\hline $\mathrm{H} 3$ & & NS & $\rightarrow$ & $\mathrm{P}$ & 0,597416 & 6,564607 & Terbukti \\
\hline $\mathrm{H} 4$ & & PK & $\rightarrow$ & PKM & 0,527549 & 7,386897 & Terbukti \\
\hline \multirow[t]{2}{*}{$\mathrm{H} 5$} & a & PNG & $\rightarrow$ & PUTM & 0,155678 & 1,889879 & Terbukti \\
\hline & b & SK & $\rightarrow$ & PUTM & 0,064164 & 0,405975 & $\begin{array}{c}\text { Tidak } \\
\text { Terbukti }\end{array}$ \\
\hline $\mathrm{H} 6$ & & PKM & $\rightarrow$ & PUTM & 0,202027 & 1,980176 & Terbukti \\
\hline H7 & & PK & $\rightarrow$ & PUTM & 0,025687 & 2,198049 & Terbukti \\
\hline $\mathrm{H} 8$ & & PUTM & $\rightarrow$ & PN & 0,165998 & 1,737444 & Terbukti \\
\hline $\mathrm{H} 9$ & & $\mathrm{KL}$ & $\rightarrow$ & PN & 0,419738 & 3,423415 & Terbukti \\
\hline $\mathrm{H} 10$ & & $\mathrm{KL}$ & $\rightarrow$ & $\mathrm{KP}$ & 0,449065 & 4,597494 & Terbukti \\
\hline H11 & & PN & $\rightarrow$ & $\mathrm{KP}$ & 0,146217 & 1,755199 & Terbukti \\
\hline
\end{tabular}

Berdasarkan tabel 4, dapat dijelaskan bahwa kriteria penerimaan dan penolakan hipotesis, dimana Ho diterima jika $p \geq \alpha$ atau nilai $t_{\text {hitung }} \leq \mathrm{t}_{\text {tabel }}$ dan Ha diterima jika $p<\alpha$ atau nilai $\mathrm{t}_{\text {hitung }}>\mathrm{t}_{\text {tabel. }}$

\section{SIMPULAN}

Berdasarkan hasil penelitian, peneliti dapat menyimpulkan bahwa :

1. Variabel-variabel eksternal yang terdiri dari PNG, P, RP, HD berpengaruh positif dan signifikan terhadap PKM, sedangkan variabel eksternal yang terdiri dari NS dan KO tidak berpengaruh terhadap PKM.

2. Variabel-variabel eksternal yang terdiri dari KDDK, KPK, PSPK, dan
KOB berpengaruh positif dan signifikan terhadap PK sedangkan variabel eksternal yang terdiri dari PKE dan KYD tidak berpengaruh terhadap PK.

3. Variabel eksternal NS berpengaruh positif dan signifikan terhadap P dari sistem informasi akademik.

4. PK berpengaruh positif dan signifikan terhadap PKM dari sistem informasi akademik.

5. Variabel eksternal dari PNG berpengaruh positif dan signifikan terhadap PUTM dari sistem informasi akademik, dan variabel eksternal dari SK tidak berpengaruh terhadap PUTM dari sistem informasi akademik.

6. PKM berpengaruh positif dan signifikan terhadap PUTM dari sistem informasi akademik.

7. PK berpengaruh positif dan signifikan terhadap PUTM dari sistem informasi akademik.

8. PUTM berpengaruh positif dan signifikan terhadap PN dari sistem informasi akademik.

9. KL berpengaruh positif dan signifikan terhadap PN dari sistem informasi akademik.

10. KL berpengaruh positif dan signifikan terhadap KP dari sistem informasi akademik. 
11. PN berpengaruh positif dan signifikan terhadap KP dari sistem informasi akademik.

\section{DAFTAR PUSTAKA}

[1] Davis, F.D., 1986, TAM for empirically testing new end-user information systems: theory and results, Doctoral Dissertation, Sloan School of Management, Massachusetts Institute of Technology.

[2] Sugiyono., 2005, Metodologi Penelitian Bisnis, Cetakan Kelima, Bandung: Alfabeta.

[3] Dennis Ananta, Fitria-, 2017, Implementasi Sistem Informasi perangkat Lunak Nilai Akademik Siswa, Jurnal Informatika Vol 17 no 2 pp.39 - 45

[4] Ghozali, Imam., 2006, Aplikasi Structural Equation Modeling, Metode Alternatif dengan Partial Least Square (PLS), Edisi Pertama, Badan Penerbit Universitas Diponegoro, Semarang.

[5] Arikunto, Suharsimi., 2013, Prosedur Penelitian: Suatu Pendekatan Praktik, PT. Rineka Cipta, Jakarta.

[6] Relawati., 2014, Analisa Pengukuran Tingkat Kepuasan Pengguna Layanan Perpustakaan dengan Menggunakan
Metode Technology Acceptance Model, Pelita Informatika Budi Darma, Vol. VI, No. 2.

[7] Susanto, Tri; Sudarmawan; Marco, Robert., 2013, Evaluasi terhadap Sistem Informasi di STMIK AMIKOM menggunakan Technology Acceptance Model (TAM), Dalam Seminar Nasional Teknologi Informasi dan Multimedia, 2013 (ISSN: 2302-3805), Yogyakarta, 2013.

[8] Hilli, A. Yusten., 2013, Kajian perilaku pengguna sistem informasi akademik UKSW berbasis web dalam peningkatan kinerja akademik mahasiswa menggunakan model kesuksesan Delone dan McLean dengan modifikasi model TAM, Tesis, Universitas Kristen Satya Wacana, Salatiga.

[9] Istianingsih., 2009, Pengaruh kualitas sistem informasi, perceived usefulness dan kualitas informasi terhadap kepuasan pengguna akhir software akuntasi, Bidang kajian riset SI akuntasi, Universitas Indonesia.

[10] Wibowo, Arief., 2007, Kajian tentang perilaku penggunaan sistem informasi dengan pendekatan Techology Acceptance Model (TAM), Universitas Budi Luhur, Jakarta Selatan. 